\title{
Acute Toxicity by Water Containing Hexavalent or Trivalent Chromium in Native Brazilian Fish, Piaractus mesopotamicus: Anatomopathological Alterations and Mortality
}

\author{
Marcello Pardi Castro • Flávio Ruas de Moraes • \\ Rodrigo Yudi Fujimoto • Claudinei da Cruz • \\ Marco Antonio de Andrade Belo • Julieta Rodini Engrácia de Moraes
}

Received: 14 May 2013/Accepted: 2 December 2013/Published online: 18 December 2013

(C) Springer Science+Business Media New York 2013

\begin{abstract}
This study evaluated the toxicity of hexavalent and trivalent compounds of chromium to the pacu, Piaractus mesopotamicus, in acute exposures of $96 \mathrm{~h}$ through mortality and histopathological responses. Hexavalent potassium dichromate was more toxic than trivalent compounds of chromium chloride, chromium oxide and chromium carbochelate. Sufficient mortalities occurred only with potassium dichromate to yield an $\mathrm{LC}_{50}$ value at $124.2 \mathrm{mg} \mathrm{L}^{-1}$. Hexavalent chromium caused reversible and irreversible lesions, which may affect organ functionality. Histopathological evaluation showed that trivalent chromium caused lesions of lower severity. Pacu subjected to different concentrations of chromium carbochelate
\end{abstract}

M. P. Castro - F. R. de Moraes ( $\square)$ · J. R. E. de Moraes

Departamento de Patologia Veterinária, Faculdade de Ciências

Agrárias e Veterinárias Unesp, Via Prof. Paulo Donato

Castelane, km 05., Jaboticabal, SP 14884-900, Brazil

e-mail: fruas@fcav.unesp.br; fruasmoraes@gmail.com

M. P. Castro

e-mail: castromarcello@hotmail.com

J. R. E. de Moraes

e-mail: jrmoraes@fcav.unesp.br

R. Y. Fujimoto

Brazilian Agricultural Research Corporation-EMBRAPA,

Sergipe, Brazil

e-mail: ryfujim@hotmail.com

C. da Cruz

Center for Studies and Research in Environmental Matology,

Jaboticabal, Brazil

e-mail: cruzcl@yahoo.com

M. A. de Andrade Belo

Laboratory of Animal Pharmacology and Toxicology, Camilo

Castelo Branco University, Descalvado, Brazil

e-mail: maabelo@hotmail.com showed no histopathological changes in the kidneys, liver, skin and gills, being similar to those of the control fish. Among the three sources of $\mathrm{Cr}^{3+}$, only chromium chloride at $200 \mathrm{mg} \mathrm{L}^{-1}$ resulted in mortality, which reached $100 \%$ within the first $18 \mathrm{~h}$. These findings confirm that trivalent chromium, when administered within recommended levels, may be used safely in aquaculture.

Keywords Chromium - Toxicity $\cdot$ Piaractus mesopotamicus $\cdot$ Histopathology

Chromium is a transition element and only its trivalent and hexavalent forms have biological significance. Trivalent chromium is more common in nature, while hexavalent chromium is of industrial importance (Fujimoto et al. 2008).

Addition of trivalent chromium to the diet $(2 \mathrm{mg}$ of $\mathrm{Cr}_{2} \mathrm{O}_{3} / \mathrm{kg}$ of feed) of pacu (Piaractus mesopotamicus) improves production in the form of increased weight gain, energy deposition and hepatic glycogen; and boosts the action of insulin (Fujimoto et al. 2005). It also favors an increased accumulation of protein and a reduction in the fat content of the carcass (Fujimoto et al. 2007).

Hexavalent chromium compounds are carcinogenic (Krumschnabel and Nawaz 2004) and are used in chromium plating, and cement and paint production industries, presenting high potential for contamination of aquatic environments (Fujimoto et al. 2007). The gills of Channa punctatus exposed to $\mathrm{Cr}^{6+}$ exhibited hyperplasia of the lamellar epithelium, lamellar fusion and necrosis (Mishra and Mohanty 2008). The concentrations of trivalent and hexavalent chromium in water are regulated by oxidationreduction in the presence of the other half of the redox pair. In polluted environments with low oxygen concentrations, 
the generation of hexavalent chromium is favored by the oxidation of trivalent chromium (Richard and Bourg 1991).

Trivalent chromium is used in aquaculture to diminish stress and enhance production. Supplementation with chromium has been demonstrated to improve immune response of Oreochromis niloticus challenged with Aeromonas hydrophyla (Castro 2012). However, there is the possibility of harmful effects on the fish that are being raised, as well as on non-target organisms, from chromium residues in effluents discharged from the aquaculture facilities. Thus, the present study had the aim of evaluating the acute toxicity and possible damage to tissues of pacu maintained in water containing different concentrations of trivalent (chromium chloride, chromium oxide and chromium carbochelate) and hexavalent (potassium dichromate) chromium. The species chosen is a native teleost fish of the Parana-Paraguay Basin, and is of importance in Brazil for human consumption, angling and aquaculture. The pacu has proven to be a good bioindicator of water quality, being seriously affected by compounds such as organophosphates (Mataqueiro et al. 2009).

\section{Materials and Methods}

A total of 360 pacu (P. mesopotamicus Holmberg 1887) weighing $8.0 \pm 2.0 \mathrm{~g}$ were initially held in a $1,000 \mathrm{~L}$ tank. Three parcels of 120 fish were randomly distributed in 24 aquaria of $10 \mathrm{~L}$ with five animals each. Fish were kept for 1 week of acclimation before the start of the experiment (Ethics Committee Approval 017900-06/CEUA/FCAVUNESP), receiving a pelletized baseline diet (28\% PB and 3,500 kcal de ED/kg), supplied twice a day (9:00 a.m. and 5:00 p.m.) ad libitum. During the toxicity test, the fish did not receive any food. The variables of the water (dissolved oxygen $=5.68 \pm 0.2 \mathrm{mg} \mathrm{L}^{-1}$ and temperature $=24.9 \pm$ $0.3^{\circ} \mathrm{C}$, as measured by a YSI 55 instrument (Yellow Springs Instrument Co, Yellow Springs, OH, USA) and $\mathrm{pH}=8.0 \pm 0.2$, as measured by a YSI 63 instrument, were kept within the comfort range for these fish, so that these parameters would not influence the results (Ayroza and Scorvo 2011).

From preliminary range-finding toxicity tests, only hexavalent chromium was judged to be sufficiently toxic to conduct a full acute toxicity test. This test was performed according to guidelines in OECD 203 (2009) and ABNT (2011). Thus, six concentrations of each compound were used in these trials: potassium dichromate and chromium chloride $\left(0,100,125,150,175\right.$ and $\left.200 \mathrm{mg} \mathrm{L}^{-1}\right)$, chromium oxide $\left(0,100,200,300,400\right.$ and $\left.500 \mathrm{mg} \mathrm{L}^{-1}\right)$ and chromium carbochelate $(0,100,150,200,250$ and $300 \mathrm{mg} \mathrm{L}^{-1}$ ). All chromium compounds were provided by Tortuga Zootechnical Company-Animal Health and
Nutrition, São Paulo, Brazil. Stocking solutions were prepared as follows: chromium oxide (99.9\% purity), a solution of $15 \mathrm{~g}$ of chromium oxide in $15 \mathrm{~L}$ of water; chromium carbochelate $(0.5 \%$ purity), a solution of $10 \mathrm{~g}$ of carbochelate in $10 \mathrm{~L}$ of water; chromium chloride (97.9\% purity), a solution of $10.31 \mathrm{~g}$ in $10 \mathrm{~L}$ of water; potassium dichromate (99.9\% purity) in a solution of $18 \mathrm{~g}$ of dichromate/18 L of water. Aliquots of the stock solutions were used to prepare the various nominal test concentrations.

To evaluate possible structural damage to tissue caused by the two forms of chromium, the fish that died during the trial plus one fish from each aquarium that survived for more than $96 \mathrm{~h}$ were necropsied. Fragments of kidney, skin, gills and liver were collected and fixed in $10 \%$ buffered formalin for $24 \mathrm{~h}$. After that, the fragments were treated in accordance with standard histological techniques to obtain semi-serial sections of $5 \mu \mathrm{m}$ in thickness, which were stained using hematoxylin/eosin.

For this trial, a fully randomized design was used, with six treatments and three repetitions. The interval between the observations was six $\mathrm{h}$, and the experiment was performed using a static system. The method used for determining the $\mathrm{LC}_{50-96 \mathrm{~h}}$ was the trimmed Spearman-Karber technique (Hamilton et al. 1977).

\section{Results and Discussion}

At the concentrations of 125,150 and $175 \mathrm{mg} \mathrm{L}^{-1}$ of chromium chloride, oxide and carbochelate, no behavioral abnormalities or mortality were observed. Consequently, the $\mathrm{LC}_{50-96 \mathrm{~h}}$ could not be determined at the concentrations used. Only the concentration of $200 \mathrm{mg} \mathrm{L}^{-1}$ of chromium chloride caused mortality, showing total mortality in the first $18 \mathrm{~h}$. These results are in agreement with those found by several authors who proved that if $\mathrm{Cr}^{3+}$ was administered within the safety levels, it did not cause health problems for humans or animals (Institute of Medicine 2003). There was no genotoxic effect on humans and the cell changes due to supplementation resulted from contamination with $\mathrm{Cr}^{6+}$. Inorganic $\mathrm{Cr}^{3+}$ rarely crosses cell membranes: it has low reactivity and low toxicity, especially in the organic form. The ratio between useful concentration and toxic concentration is approximately 1:10,000; i.e., it can be considered safe for use in animal nutrition (Institute of Medicine 2003). The results found here corroborated this information.

In a resolution in 1986, the Brazilian regulatory agency CONAMA established limits for $\mathrm{Cr}^{3+}$ concentrations of $0.5 \mathrm{mg} \mathrm{L}^{-1}$ for class 2 water (designated for fish farming) and $2.0 \mathrm{mg} \mathrm{L}^{-1}$ for its effluents. However, it needs to be emphasized that, despite the low toxicity of $\mathrm{Cr}^{3+}$, it may 
undergo oxidation-reduction under conditions of low dissolved oxygen concentration, thereby transforming it into the hexavalent form or another toxic valency, and vice versa. Environments with low oxygen concentrations favor the formation of $\mathrm{Cr}^{6+}$, which is easily absorbed by living beings within the local ecosystem (Richard and Bourg 1991). Thus, dietary supplementation in animal feed should be chosen in such a way as to have the minimum possible carryover in the breeding environment. The results from the $\mathrm{Cr}^{6+}$ toxicity test showed that deaths began after $18 \mathrm{~h}$, and continued until $96 \mathrm{~h}$ after administration. The highest mortality rate was between 48 and $96 \mathrm{~h}$ after administration, at the concentrations of 175 and $200 \mathrm{mg} \mathrm{L}^{-1}$, thus suggesting that there was a cumulative biological effect that continued to cause toxicity through $96 \mathrm{~h}$ of exposure, when $100 \%$ mortality was reached.

The 96-h $\mathrm{LC}_{50}$ for $\mathrm{Cr}^{6+}$ was $124.23 \mathrm{mg} \mathrm{L}^{-1}$. This followed the linear equation $y=0.1346 x-10.177$, where " $y$ " is mortality and " $\mathrm{x}$ " is the $\mathrm{Cr}^{6+}$ level, with a high coefficient of determination: $\mathrm{R}^{2}=0.9344$ (Fig. 1). This metal accumulates in aquatic organisms through passive diffusion caused by the tetrahedral chromate anion, in the same way as occurs with other natural anions such as sulfates and phosphates, which cross the canals of the cell membrane (Li and Elmendorf 2001).

Different degrees of sensitivity to $\mathrm{Cr}^{6+}$ for different species of fish have been indicated in the literature. According to Garton (1973), the 96-h $\mathrm{LC}_{50}$ for rainbow trout, Salmo gairdneri, was $14 \mathrm{mg} \mathrm{L}^{-1}$; Abbasi and Soni (1984) obtained an $\mathrm{LC}_{50}$ of $28.9 \mathrm{mg} \mathrm{L}^{-1}$ for channel catfish, Ictalurus punctatus; and for goldfish, Carassius auratus, it was $37.5 \mathrm{mg} \mathrm{L}^{-1}$ (Pickering and Henderson 1996). The results from the present trial demonstrate that pacus are more tolerant of $\mathrm{Cr}^{6+}$ than the species cited above. Thus, pacu may reach higher bioaccumulations of this metal, representing greater risk to human health. The hexavalent form is carcinogenic and mutagenic (Institute of Medicine, 2003) because it easily crosses cell membranes to react with proteins and nucleic acids. These reactions are

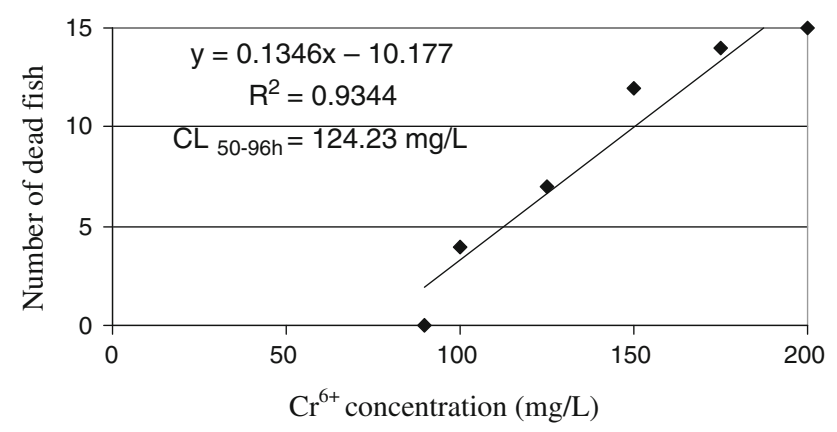

Fig. 1 Plot of concentration versus mortality for the acute test with $\mathrm{Cr}^{6+}$ and pacu the basis for its carcinogenicity (Krumschnabel and Nawaz 2004), and present a high aggressive potential in water, as in the present trial. CONAMA's 1986 resolution on human health and wellbeing established limits for $\mathrm{Cr}^{6+}$ of 0.05 and $0.5 \mathrm{mg} \mathrm{L}^{-1}$ for water used in aquaculture and for effluents from aquaculture facilities, respectively. Thus, there is a wide safety margin before reaching the lethal concentration of $124.2 \mathrm{mg} \mathrm{L}^{-1}$ that was found in the present trial, or the concentration of $14 \mathrm{mg} \mathrm{L}^{-1}$ observed by Garton (1973) for rainbow trout. Nonetheless, it needs to be borne in mind that the results indicated here relate to acute toxicity trials, and that the effects from chronic exposure to chromium remain unknown, in relation both to fish and to individuals who consume them.

At concentrations of 100, 125, 150 and $175 \mathrm{mg} \mathrm{L}^{-1}$ of potassium dichromate, fish did not present any abnormalities. However, at the concentration of $200 \mathrm{mg} \mathrm{L}^{-1}$, thickening of the stratified squamous epithelium of the epidermis was observed, with hyperplasia and hypertrophy of cells in the external, intermediate and basal layers, particularly in the mucous cells; as well as increased numbers of chromatophores. Caliciform cells produce neutral mucous substances that are PAS+(Periodic Acid Schiff positive), and $\mathrm{Cr}^{6+}$ may induce increases in their numbers and production of mucus as a means of protecting the epithelium (Alzemi et al. 1996).

Chromium oxide at the concentration of $100 \mathrm{mg} \mathrm{L}^{-1}$ did not present abnormalities, but at the concentrations of 200, 300, 400 and $500 \mathrm{mg} \mathrm{L}^{-1}$, there was a gradual increase in the interstitial space between the epidermis and the connective tissue layer (Fig. 2). Anderson (1994) explained the hyperplasia and hypertrophy of caliciform and clavate cells as a form of adaptation to the effect of pollutants. Thus, the increase in the size of the interstitial space between the dermis and the epidermis observed here may result from edema, as a means of diluting the chromium that is absorbed by the skin.

In the livers of the fish kept in the concentration of $100 \mathrm{mg} \mathrm{L}^{-1}$ of potassium dichromate, vascular congestion was observed while the tissue architecture was maintained. At the concentration of $125 \mathrm{mg} \mathrm{L}^{-1}$, changes similar to those described for $100 \mathrm{mg} \mathrm{L}^{-1}$ were found.However, from $150 \mathrm{mg} \mathrm{L}^{-1}$ onwards, discrete hypertrophy of the hepatocytes with slight cordonal disordering was observed. These changes were most severe in the fish subjected to the treatment with $200 \mathrm{mg} \mathrm{L}^{-1}$, which presented cordonal disordering of hepatocytes and steatosis (Fig. 3). According to Roberts and Oris (2004), the liver is sensitive to intoxication and metabolic changes, thereby resulting in steatosis and focal necrosis. Tagliari et al. (2004) reported the presence of degenerative processes and hepatic necrosis caused by hexavalent chromium, but not circulatory changes such as the congestion observed here. Steatosis 
Fig. 2 Photomicrographs of the epidermis of pacu A control without chromium and exposed to $\mathbf{B} 200 \mathrm{mg} \mathrm{L}^{-1}$,

C $300 \mathrm{mg} \mathrm{L}^{-1}$, D $400 \mathrm{mg} \mathrm{L}^{-1}$ and $\mathbf{E} 500 \mathrm{mg} \mathrm{L}^{-1}$ of chromium oxide. (hematoxylin and eosin staining). $d$ Dermis.

$e$ Epidermis. Scales (left right arrow). Arrow chromatophores. Detail of the increase in the interstitial space between the layer of connective tissue of the dermis and the epidermis (32 $\mu \mathrm{m}$ for $200 \mathrm{mg} \mathrm{L}^{-1}, 44 \mu \mathrm{m}$ for $300 \mathrm{mg} \mathrm{L}^{-1}, 50 \mu \mathrm{m}$ for $400 \mathrm{mg} \mathrm{L}^{-1}$ and $72 \mu \mathrm{m}$ for $500 \mathrm{mg} \mathrm{L}^{-1}$, respectively)
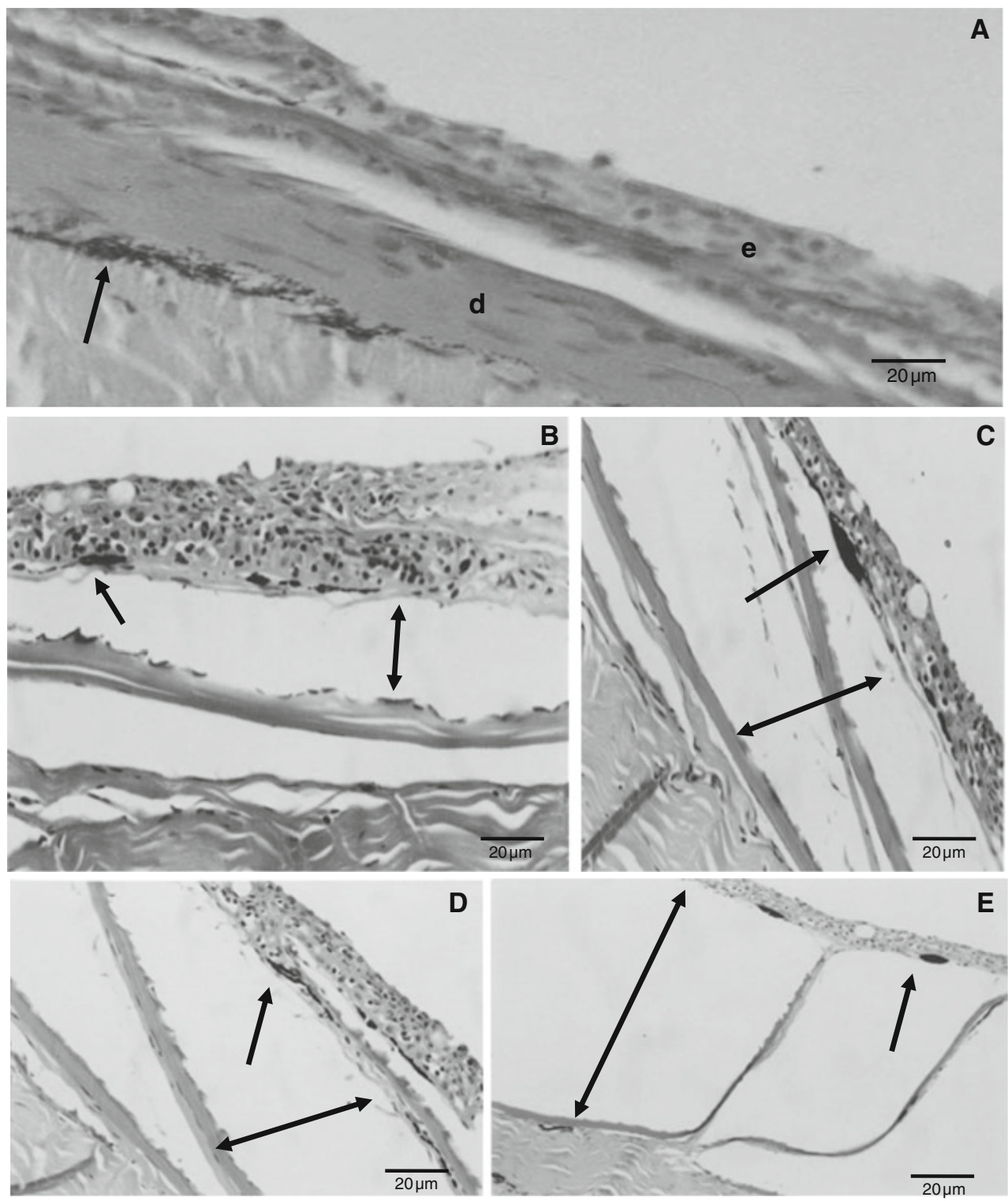

and necrosis may result from toxic processes, in accordance with Belo et al. (2012a). Animals and humans are continuously exposed to different kinds of substances such as heavy metals, pesticides, industrial residues and others undesirable contaminants, and many of these chemicals induce a free radical-mediated lipid peroxidation process that can lead to disruption of biomembranes and dysfunction of cells and tissues.

Krumschnabel and Nawaz (2004) demonstrated a significant increase of the formation of reactive oxygen species (ROS) in isolated hepatocytes of telost fish exposed to hexavalent chromium. However, in the present trial, the hepatic abnormalities in the fish subjected to hexavalent chromium may have resulted from intoxication. Ohta et al. (2006) showed the hepatoprotective effect of the neutropenia caused by the administration of antineutrophil antiserum on the decrease in the inflammatory response after the induction of acute liver toxicity. According to these authors, the suppression of the inflammatory reaction reduces the severity of the aggressions suffered by the hepatic tissue. Many studies have been designed to understand the inflammatory process in teleost fish (Belo et al. 2005, 2012b; Reque et al. 2010; Claudiano et al. 2013).

Fish exposed to trivalent chromium oxide and chromium carbochelate did not present any hepatic abnormalities. However, fish exposed to $200 \mathrm{mg} \mathrm{L}^{-1}$ chromium chloride exhibited vacuolization of the hepatocyte cytoplasm after 12-18 h of treatment.Berner et al. (2004) did not find any abnormalities in the livers of rats that were fed with trivalent chromium over a 20 -week period, differing from the present findings. Fujimoto et al. (2005) reported similar 

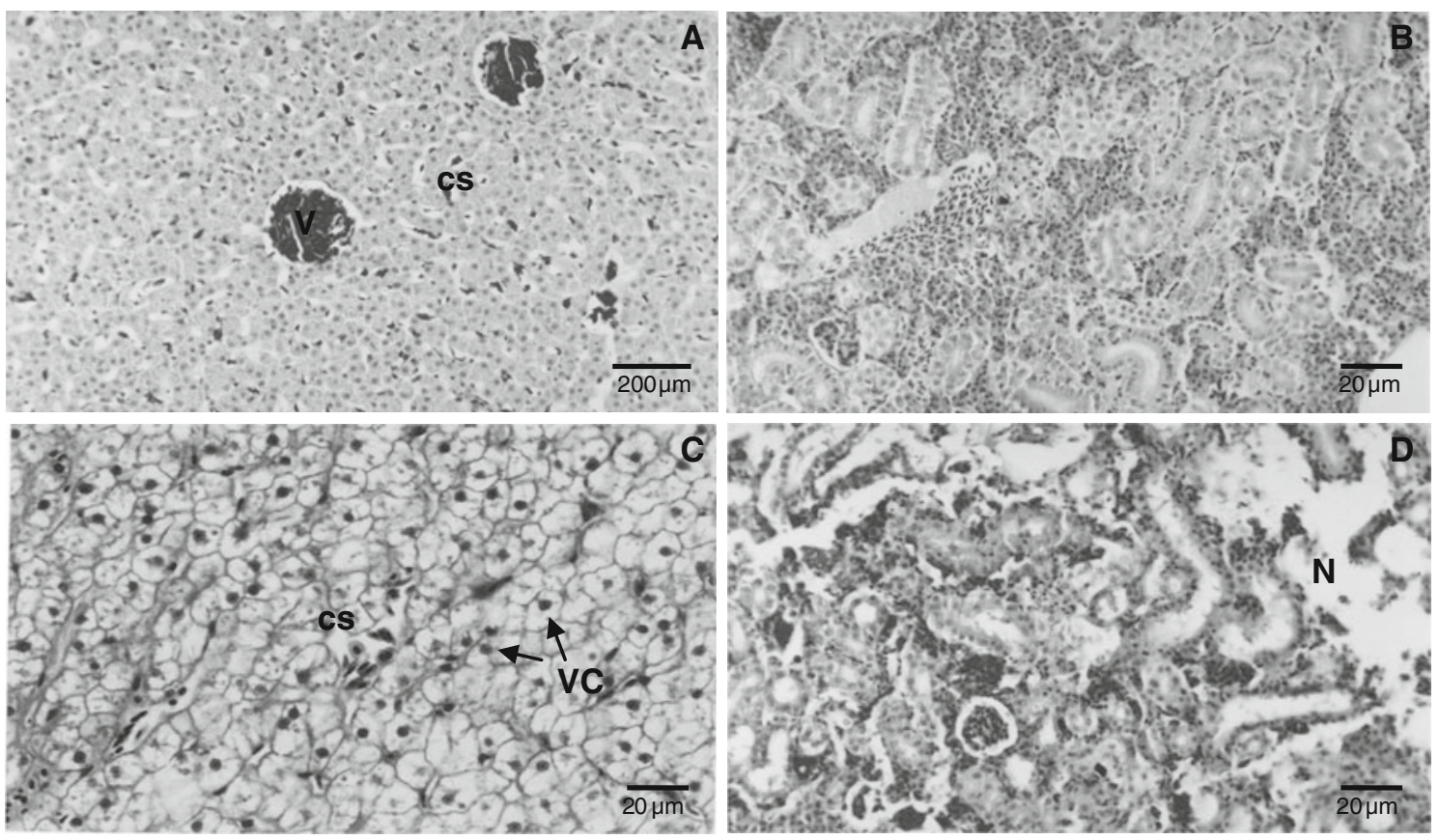

Fig. 3 Photomicrographs of $\mathbf{A}$ liver and $\mathbf{B}$ kidney of pacu in the control group without chromium. C liver and D Kidney of pacu exposed to $200 \mathrm{mg} \mathrm{L}^{-1}$ potassium dichromate for $96 \mathrm{~h}$. Note the

disordering of the cordonal structure $(C S)$ and the vacuolization $(V C)$ presented in the liver, and focal necrosis in the kidney $(N)$. (hematoxylin and eosin staining)
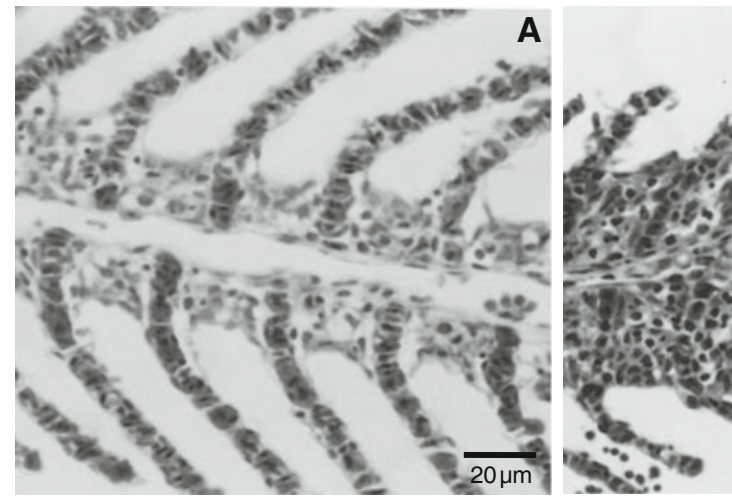

Fig. 4 Photomicrographs of gill filament of P. mesopotamicus in the control group without chromium (A) and exposed to $200 \mathrm{mg} \mathrm{L}^{-1}$ chromium chloride: $\mathbf{B}$ congestion of sinusoid capillaries and

hepatic abnormalities and others of greater severity such as necrosis, in pacus that were given food supplemented with trivalent chromium, which were not found in the present study with the use of trivalent chromium. Thus, especially in relation to the liver, which has the task of detoxification of endogenous and exogenous toxic products involving different types of toxins, drugs, heavy metals and pesticides in general, hexavalent chromium is potentially more aggressive ( $\mathrm{Li}$ et al., 2011). This emphasizes the importance of knowing the ideal level of chromium, along with the length of exposure and administration route. interlamellar epithelial hyperplasia and $\mathbf{C}$ epithelial hyperplasia with complete filling of the interlamellar space and lamellar fusion in dead pacu (hematoxylin and eosin staining)

Microscopic examination of the cephalic kidneys of fish exposed to $150-200 \mathrm{mg} \mathrm{L}^{-1}$ hexavalent chromium showed cell degeneration and focal necrosis (Fig. 3). Fujimoto et al. (2008) did not describe any morphological abnormalities in the kidneys of pacus that were fed with diets supplemented with trivalent chromium. In our study, the kidneys of pacu exposed to chromium carbochelate and chromium oxide did not present any notable morphological changes. Moreover, in the treatment with chromium chloride, only the concentration of $200 \mathrm{mg} \mathrm{L}^{-1}$ showed slight congestion. According to Tagliari et al. (2004), the 
morphological changes caused by chromium, such as cell degeneration and necrosis, correlated with the length of exposure. Thus, the $96 \mathrm{~h}$ period used for the acute toxicity test may not have been sufficient to cause renal damage, which might have been observed histologically. Heavy metals and agricultural chemicals may act indirectly to cause metabolic anomalies, and some modifications may take place through overloading.

Only the concentrations of $500 \mathrm{mg} \mathrm{L}^{-1}$ chromium oxide and $200 \mathrm{mg} \mathrm{L}^{-1}$ chromium chloride produced morphological abnormalities in the gills, such as severe hyperplasia of the lamellar epithelium and structural disorganization of the lamellae. Gill tissue in fish exposed to the other concentrations of chromium oxide, chromium chloride and chromium carbochelate appeared similar to controls (Fig. 4).

Many agents produce hyperplastic and degenerative circulatory abnormalities resulting from defensive responses to infections or pollutants (Mishra and Mohanty 2008). Nath et al. (1997) found that when the gills of banded gourami, Colisa fasciatus, were exposed to sublethal concentrations of hexavalent chromium $\left(48 \mathrm{mg} \mathrm{L}^{-1}\right)$, they suffered considerable damage. Among such damage was hypertrophy and hyperplasia of the lamellar epithelium, which was confirmed by the present observations. According to Mishra and Mohanty (2008), these abnormalities can be explained by the fact that the gills are the main entry route for chromium dissolved in water and, consequently, they are the location with the greatest accumulation. Hyperplasia is a compensatory mechanism allowing the organism to adapt such that the oxygen absorption surface is increased, with the aim of normalizing respiration.

In conclusion, it was found that hexavalent chromium was more toxic than the trivalent forms, and that it caused either reversible lesions such as steatosis or edema, or irreversible ones such as tissue necrosis. These lesions affect not only the structure but also the functionality of these organs. Among the trivalent compounds, only chromium chloride at $200 \mathrm{mg} \mathrm{L}^{-1}$ caused mortality. Histopathological evaluation showed that trivalent chromium caused lesions of lower severity. These findings confirm that trivalent chromium, when administered within recommended levels, may be used safely in aqualculture. Pacu subjected to different concentrations of trivalent chromium in the organic form of chromium carbochelate showed no histopathological changes in the kidneys, liver, skin or gills, relative to the control fish. Among the trivalent chromium compounds, the one that presented higher toxicity was chromium chloride, which caused complete mortality within the first $18 \mathrm{~h}$.

Acknowledgments This research was financed by FAPESP, Research Foundation of São Paulo State, Process Number: 05/57989-8.

\section{References}

Abbasi SA, Soni R (1984) Toxicity of flower than permissible levels of chromium IV to the freshwater teleost Nuria denricus. Environ Pollut A 36:75-82

ABNT-Brazilian Association of Technical Standards, NBR 15088 (2011) Aquatic ecotoxicology - acute toxicology, method of bioassay for fish. São Paulo, $19 \mathrm{p}$

Alzemi BM, Lewis JW, Andrews EB (1996) Gill damage in freshwater fish Gnathonemus petersii (family: Mormyridae) exposed to selected pollutants: an ultrastructural study. Environ Sci Technol 17:225-238

Anderson RA (1994) Stress effects on chromium nutrition of humans and farm animals. Biotechnol Feed Industry. Nicholasville: Alltech. Tech. Pub. 10:267-273

Ayroza DMMR, Scorvo CMDF (2011) Quality of water for aquaculture. In: Ayroza LMS.(ed) Piscicultura. Manual técnico 79. CATI - Campinas

Belo MAA, Schalch SHC, Moraes FR, Soares VE, Otoboni A, Moraes JRE (2005) Effect of dietary supplementation with vitamin $\mathrm{E}$ and stocking density on macrophage recruitment and giant cell formation in teleost fish Piaractus mesopotamicus. J Comp Pathol 133:146-154

Belo MAA, Soares VE, Souza LM, Sobreira MFR, Cassol DMS, Toma SB (2012a) Hepatoprotective treatment attenuates oxidative damages induced by carbon tetrachloride in rat. Exp Toxicol Pathol 64:155-165

Belo MAA, Moraes JRE, Soares VE, Martins ML, Brum CD, Moraes FR (2012b) Vitamin C and endogenous cortisol in foreign-body inflammatory response in pacus. Pesq Agropec Bras 47: $1015-1021$

Berner TO, Murphy MM, Slesinski R (2004) Determining the safety of chromium tripicolinate for addition to foods as a nutrient supplement. Food Chem Toxicol 42:1029-1042

Castro MP (2012) Growth performance and acute inflammation in nile tilapia supplemented with chromium carboquelate and cell wall of Saccharomyces cerevisiae. São Paulo State University, Jaboticabal, Doctoral thesis presented in the Veterinary Medicine post graduate program $87 \mathrm{pp}$

Claudiano GS, Petrillo TR, Manrique WG, Castro MP, Loureiro BA, Marcusso PF, Belo MAA, Moraes JRE, Moraes FR (2013) Acute aerocystitis in Piaractus mesopotamicus: participation of eicosanoids and pro-inflammatory cytockines. Fish Shellfish Immunol 34:1057-1062

CONAMA, National Council of Enviroment (1986) Resolution number 20 published July 30th by the Brazilian official Dairy, Brasília

Fujimoto RY, Castro MP, Moares FR, Gonçalves FD (2005) Effect of diet supplementation with trivalent chromium on Piaractus mesopotamicus (Holmberg, 1887) at different stocking densities. Physiological parameters. Bol Inst Pesca 31:155-162

Fujimoto RY, Castro MP, Honorato CA, Moraes FR (2007) Body composition and nutrient efficiency use by pacus fed on ration supplemented with chromium. Pesq Agropec Bras 42:1763-1768

Fujimoto RY, Cruz C, Moraes FR (2008) Analysis of effluents and histology of skin, liver and kidney of the pacus (Piaractus mesopotamicus) supplemented with trivalent chromium. Bol Inst Pesca 34:117-124

Garton RB (1973) Biological effects of cooling tower blowdown. Am Inst Chem Eng J 69:284-292

Hamilton MA, Russo RC, Thurston V (1977) Trimmed SpearmanKarber method for estimating medial lethal concentrations in toxicity bioassays. Environ Sci Technol 7:714-719

Institute of Medicine (2003) Dietary reference intake for vitamin A, $\mathrm{K}$, arsenic, boron, chromium, copper, iodine, iron, manganese, 
molybdenum, nickel, silicon, vanadium and zinc. National Academic Press, Washington 800p

Krumschnabel G, Nawaz M (2004) Acute toxicity of hexavalent chromium in isolated teleost hepatocytes. Aquat Toxicol 70:159167

Li P, Elmendorf JS (2001) Changes in plasma membrane architecture as a basis for chromium activated GLUT 4 translocation. Diabetes A532 (abstr. 2306-PO)

Li ZH, Li P, Randak T (2011) Evaluation of the toxicity of environmental concentrations of waterborne chromium (VI) to a model teleost, Oncorhynchus mykiss: a comparative study of in vivo and in vitro. Comp Biochem Physiol C: Toxicol Pharmacol 153:402-407

Mataqueiro MI, Souza JP, Cruz C, Urbinati EC, Nakaghi LS (2009) Histopathological changes in the gill, liver and kidney of pacu (Piaractus mesopotamicus, Holmberg, 1887) exposed to various concentrations of trichlorfon. J Appl Ichthyol 25:124-129

Mishra AK, Mohanty B (2008) Histopathological effects of hexavalent chromium in the ovary of a fresh water fish, Channa punctatus (Bloch). Bull Environ Cont Toxicol 80:507-511

Nath K, Kumar N, Srivastav AK (1997) Chromium induced histological alterations in the gills of a freshwater teleost. Colisa fasciatus Fish Biol J Medaka 9:37-40
OECD 203 (2009) Guideline for testing of chemicals. Fish, acute toxicity test. OECD, Paris, p 9

Ohta Y, Imai Y, Matsura T, Kitagawa A, Yamada K (2006) Preventive effect of neutropenia on carbon tetrachloride-induced hepatotoxicity in rats. J Appl Toxicol 26:178-186

Pickering QH, Henderson C (1996) The acute toxicity of some heavy metals to different species of warm water fishes. Air Water Pollut J 10:453-463

Reque VR, Moraes JRE, Belo MAA, Moraes FR (2010) Inflammation induced by inactivated Aeromonas hydrophila in Nile tilapia fed diets supplemented with Saccharomyces cerevisiae. Aquaculture 300:37-42

Richard FC, Bourg ACM (1991) Aqueous geochemistry of chromium: a review. Water Resour 25:807-816

Roberts AP, Oris JT (2004) Multiple biomarkers responses in rainbow trout during exposure to hexavalent chromium. Comp Biochem Physiol 138:221-228

Tagliari KC, Vargas VMF, Zimiani K, Cecchini R (2004) Oxidative stress damage in the liver of fish and rats receiving a intraperitoneal injection of hexavalent chromium as evaluated by heminoluminescence. Environ Toxicol Pharmacol 17: $148-157$ 